\title{
A New Keyword in the Museum: Exhibiting the Anthropocene
}

\author{
Lotte Isager, Line Vestergaard Knudsen, Ida Theilade
}

\begin{abstract}
Since 2000, the concept of the Anthropocene has moved from its geologic field of origin into numerous other academic disciplines and into the world of museums. Based on journal papers, exhibition reviews and online material, this paper describes 41 exhibitions about the Anthropocene, analyzes how museums and galleries understand the Anthropocene, and how they use exhibition media as well as their authority as museums in dealing with this topic. It is argued that exhibitions generally display the Anthropocene as an unsettled category. Audiences are presented with complex factual accounts and highly emotional images of the past and the future. They are invited to reflect upon the Anthropocene not as a well-defined issue but as heritage in the sense of 'transformable practices' (Harrison 2015: 34). However, most exhibitions appear to deliberately exclude significant controversies about the Anthropocene and the predicament of the world from their arenas for reflection.
\end{abstract}

Keywords: Anthropocene; Museum; Heritage; Future assembling.

Had he lived today, the British literary scholar, novelist, playwright, cultural historian and theorist Raymond Williams would most probably have included Anthropocene in his collection of 'Keywords' (Williams 1976). In Culture and Society, Williams argued that cultural production and communication are integral parts of the development of industrial capitalism, rather than being mere reflections of economic and political power (Williams 1958), and in The Long Revolution he strongly advocated for the significance of publicly owned mass media and communication channels (Williams 1961). While working on these publications Williams collected a list of words with a history of complicated semantics and semantic change, including democracy, art, family, class, civilization, science, and individual. He eventually published this list as Keywords in 1976 (revised in 1983) to show that social and historical processes occur, in part at least, within language when new kinds of meanings and relationships and new ways of seeing existing relationships appear.

In this article, we investigate the Anthropocene as a new keyword in the museum. While some words, e.g. culture, nature, society, and class, grow into keywords after centuries of accumulating new meanings, other keywords attain this status rapidly after the invention of a new term. This is the case with the Anthropocene. After chemist Paul J. Crutzen and biologist Eugene F. Stoermer (2000) proposed Anthropocene as the name of the current geological epoch defined by humankind's profound disturbance of the Earth's atmosphere and ecosystems, this term almost instantaneously found its way into scientific debates, research programs, conferences, courses, books, papers and academic journals. The Anthropocene is therefore among the rare scientific concepts with sufficient X-factor to cross over from its scholarly field of origin into virtually every other academic discipline, into the worlds of politics and the arts, into mass media and into the world of museums. This ability to create connections between several different areas of public life and debate is an essential quality in a keyword (Williams 1976). 
According to international statutes a museum is due to serve society and its development as it 'acquires, conserves, researches, communicates and exhibits the tangible and intangible heritage of humanity and its environment for the purposes of education, study and enjoyment' (ICOM, Section 1, Article 3). ${ }^{1}$ Within this broad framework numerous museum practitioners and academics have elaborated on museum responsibilities and suggested conceptual reforms of museums and their relations to surrounding societies. Among articulations of the potential societal value of museums are: Instigators of acceptance and positive approaches to cultural and social diversity (Goodnow and Akman 2008; Schorch 2013; Kreps 2015); and facilitators of safe democratizing, inclusive and polyphonic platforms for critical dialogue around socially relevant and/or controversial issues (Cameron and Kelly 2010; Tøndborg 2013; Macalik et al. 2015; Sandahl 2019) such as the environment, climate change, racial, social and gender discrimination, drugs, GMO foods, epidemics and science ethics (Einsiedel Jr. and Einsiedel 2004; Gurian 2006; Cameron and Kelly 2010; Meyer 2010; Salazar 2011; Lynch 2013). ${ }^{2}$ Museums are also described as activist forces in society (Janes \& Sandell 2019; Chynoweth et al. 2020) by speaking up for groups or issues that are not elsewhere catered for and thus, in the longer term, instigators of social change (Sandell 2003). Finally, it is relevant to mention the notion of heritage making in museums as 'past-presence' (Macdonald 2013) or 'future assembling' (Harrison 2015) practice. In this optic, museums are not only viewed as places to preserve, communicate and debate the past; the ways they present the past and intelligibly connect it to our present is also seen to matter since it affects how we act in our contemporary conditions. The exact ways that museums make issues intelligible matters, since it determines how 'actionable' audiences find them (Salazar 2014) and anticipatory practices (Newell et al. 2016) are therefore part of museums' societal provision. Museums are, in other words, significant agents and venues for public debate about what Raymond Williams called 'central processes' of our common life (Williams 1976: 14). A vital part of their raison d'être is to present to the public new ways of seeing things, new ways of attaching meanings to things and topics and the relationships between them. Museums obviously share this purpose with the educational sector, with the arts world, with religion, and with mass media.

'Museum' is neither counted among Williams' keywords in 1976 and 1983, nor is it listed in Tony Bennett et al.'s New Keywords: A Revised Vocabulary of Culture published in 2005. Between the times of publication of these volumes, the world changed markedly in terms of the conduct and circulation of intellectual work; public scrutiny and criticism of 'facts' and historical narratives; and increased inter-disciplinarity. Interestingly, the books by Williams and Bennett et al. inspired an exhibition called Keywords: Arts, Culture and Society in 1980s Britain at the Institute of International Visual Arts (Iniva) in London in 2013, which was transferred to Tate Liverpool in 2014. This exhibition juxtaposed a selection of keywords with different artworks based on the particular words. By stressing the different and, at times, conflictual artistic visions of each keyword, the exhibition not only emphasized Williams' fundamental argument in Keywords. By including a wide range of artists, it also underlined the difference between Williams' (1976) British, single authored, book-and-library based volume and Bennett et al.'s (2005) book created by a globally assembled interdisciplinary collective of internet using authors.

In recent years, several museums have explored the Anthropocene in their exhibitions. Most famously, the Deutsche Museum in Munich, Germany, in 2014-16, curated Welcome to the Anthropocene. The Carnegie Museum of Natural History in Pittsburgh, USA, followed through with the exhibitions We Are Nature (2017) and The Anthropocene Livingroom (2019). In addition to these large-scale efforts, numerous smaller-scale exhibitions in different countries, as well as exhibitions in art galleries and botanical gardens, have attempted to combine cultural history, art, science and the presentation of nature (e.g. BGCl 2010; Cannon and Kua 2017; Dunn 2017; Heywood 2017). ${ }^{3}$

Looking at these exhibitions from the analytical perspective of the Anthropocene as a new keyword in the museum, the article offers an analysis and discussion of the purposes, strategies and content that museums unfold as sites for public debate about this new geologic and historic era. Following a brief presentation of the Anthropocene as a new keyword, we use online catalogues, journal papers and exhibition reviews to describe and characterize 
exhibitions about the Anthropocene. For the analysis, we ask how museums and galleries in different countries understand the Anthropocene. What are their purposes of exhibiting the Anthropocene? How do they select and present specific aspects of this topic? And how do they deal with critiquing the concept of the Anthropocene?

In the discussion, we argue that by bringing objects and subjects from what used to be considered different realms of being into their Anthropocene exhibitions, museums seek to establish a new sense of reality, or what Harrison (2015: 33) calls a 'flat notion of the social'; that is, a notion that implies that all 'being' is interactive and is part of the same broader 'natural-cultural assemblage' (Harrison 2015: 33). However, we question how 'flat' the exhibitions actually are in the ways they portray natural-cultural assemblages in the Anthropocene. We further argue that most exhibitions appear to exclude significant controversies about the Anthropocene as a colonizing concept that essentially erases nonEuropean, or non-Western, ontologies and histories (cf. Todd 2015; Davis and Turpin 2015). Taking note of Bennett et al.'s insistence on including widely different and diverging voices in their 'Revised Keywords', we will question whether the exhibitions about the Anthropocene have met this challenge of our times.

\section{Anthropocene: A New Keyword}

Keywords range from strong, difficult and persuasive words in everyday usage to words which, beginning in particular specialized contexts, have become quite common in descriptions of wider areas of thought and experience (Williams 1976: 14). According to Williams, keywords tend to appear in clusters. This is evident when the Anthropocene is linked with climate change, global warming and resource extraction. Keywords are furthermore characterized by their plurality of meanings, which render them difficult to define with precision. In fact, defining a precise meaning for a keyword is not only impossible, it is also irrelevant because, with keywords, we are beyond the range of 'proper meaning'. 'We find a history and complexity of meanings; conscious changes, or consciously different uses; innovation, obsolescence, specialization, extension, overlap, transfer; or changes which are masked by nominal continuity [...]' (Williams 1976: 17). The plurality of the meanings of keywords is inextricably bound up with the problems they are being used to discuss (Williams 1976). The Anthropocene is no exception to this rule. It is a word that signifies 'a seldom seen entanglement of all sorts of facts and high emotions' (Davison 2015).

Even to begin with, the Anthropocene was twice-born. First, in the 1980s, it was conceptualized by Eugene Stoermer. Later, in 2000, Paul Crutzen co-created the term to mean a global condition in which human modification of the environment has become sufficiently significant to warrant termination of the Holocene geological epoch and the recognition of a new Anthropocene epoch (Crutzen and Stoermer 2000; Crutzen 2002). It is interesting that, although the term Anthropocene is a novel conception, the idea that human activity has long impacted on and possibly damaged the global environment is not (see Steffen et al. 2011; Zalasiewicz et al. 2011; Smith and Zeder 2013; Trischler 2016). But no previous term coined to capture this idea has inspired as much human action in the forms of research, dialogue, artwork, political struggle and conflict as the Anthropocene.

In 2009, an Anthropocene Working Group was formed as part of the Subcommission on Quaternary Stratigraphy to establish whether or not the Anthropocene should be accepted formally as new stratigraphic nomenclature (Zalasiewicz et al. 2008). By that time, the debate about the Anthropocene had moved into several other public arenas, prompting two practising stratigraphers to ask if the Anthropocene was to be regarded as a topic of science and stratigraphy or as 'eye-catching jargon' and 'pop-culture' (Autin and Holbrook 2012). The sarcasm of this question reflects a sense that an issue, which in Autin and Holbrook's view ought to be defined and confined among geologists and scientists from related disciplines, has been hijacked by environmental activists, artists, politicians, and virtually every other branch of academia including geographers (e.g. Davison 2008, 2015; Lorimer 2011), anthropologists (e.g. Swanson et al. 2015; Tsing et al. 2017), historians (e.g. Chakrabarty 2009, 2015; Trischler 2016), and archeologists (e.g. Ruddiman 2003, 2013; Lane 2015). This situation hardly changed after May 2019, when the Anthropocene Working Group decided by 
majority vote (29 members in favour, four members against) that the Anthropocene should be treated as a formal chrono-stratigraphic unit defined by a Global Boundary Stratotype Section and Point (GSSP) (Ogg 2004; Lundershausen 2018). Evidently, the conversation about the Anthropocene has moved, as Williams claimed happens with all keywords, beyond the range of 'proper meaning', and the multiplicity of meanings attached to the Anthropocene is bound up with the problems the word is meant to discuss.

It is beyond the scope of this article to go into detail with all the scientific and political questions associated with the Anthropocene. Suffice it here to recapture a few questions, which are relevant for the purposes of this article. The first is how to delimit the Anthropocene from the Holocene epoch preceding it. Crutzen \& Stoermer (2000) argue that the Anthropocene began with industrialization in the mid-1800s. Steffen et al. (2011) contend that the innovation of the steam engine and the rise of fossil fuel consumption in the early 1800 s marked the initial phase of the Anthropocene and that a 'Great Acceleration' of emissions of greenhouse gasses took place after the end of World War Two. Ruddiman $(2003,2013)$ instead claims that the baseline of human effect on climate started several thousand years ago and accelerated after 1750 (see also Autin and Holbrook 2012; Sayre 2012; Rull 2013; Lane 2015). Malm and Hornborg (2014), however, stress that the backdating of the Anthropocene implies a denial of the culpability of Western societies for causing climate change and environmental destruction (see also Crossland 2014: 125).

The second question we wish to highlight is whether Anthropocene is the most appropriate name for the natural and historical changes subsumed by this term. For Crutzen and Stoermer (2000), the Anthropos in the Anthropocene is a big, collective 'We, mankind' that has brought itself into trouble and needs another big 'We', alias 'the global research and engineering community [to...] guide mankind towards global, sustainable, environmental management'. In opposition to this view, another narrative holds that the Anthropocene did not come about because of actions undertaken by humankind in general. Rather, the Anthropocene is the result of actions and decisions by a small elite of mostly Western white people whose superior position in an eco-social order defined by asymmetrical global exchange of biophysical resources - including slavery and the exploitation of miners and factory workers - enabled them to invest in steam and the fossil economy, which still to this day depends on social inequity for its very existence (e.g. Malm and Hornborg 2014; Nixon 2014; Haraway 2015; Swanson et al. 2015; Todd 2015; Moore 2016; Tsing et al. 2017; Davis et al. 2019).

In place of Anthropocene other terms have been suggested, including 'Capitolocene' (Haraway 2015; Moore 2016), 'Homogocene' (Gordon Orian, cited in Rosenzweig 2001), 'Chthulucene' (Haraway 2015); and 'Plantationocene' (Davis et al. 2019). While acknowledging the problematic connotations of Anthropocene, most authors still use it such as Donna Haraway, for example, who writes: '[Anthropocene is...] focusing people on something that needs urgent attention. Besides, the term can't be dislodged now, I don't think [...]. So I'm not against it, but I really want to complicate it' (Haraway and Kenney 2015: 259).

A third question arising from debates about the Anthropocene is what to do with modernity's well-established boundaries - nature versus culture, natural history versus human history, science versus the humanities - which the concept of the Anthropocene muddles up, or even suspends (e.g. Chakrabarty 2009; 2015; Tsing et al. 2017). This aspect of the Anthropocene raises the question of what it means to be museums of 'natural history', 'cultural history' or 'art' in an epoch characterized not only by extensive loss of species among plants, insects, birds and mammals but by the collapse of the very nature-culture dichotomy that has hitherto defined museums (Kolbert 2015; Royal Botanical Garden in Kew 2016; Ceballos et al. 2017). ${ }^{4}$ Importantly, numerous scholars as well as artists with indigenous cultural backgrounds argue that this aspect of the Anthropocene is merely a realization of something which non-Western peoples have always known and still do not receive cultural credit for (e.g. Horton and Horton 2017; Tallbear and Willey 2019). Indeed, many see - and reject - the Anthropocene as a colonizing concept that essentially erases non-European, or non-Western, ontologies and histories and which should therefore not be granted any degree of legitimacy (Todd 2015: 8). 
Figure 1: Table of museums included in the study

\begin{tabular}{|c|c|c|c|}
\hline Title (and author) & Museum & Museum type & Year \\
\hline 1. Anthropocene Extinction Single artist: Swoon & ICA, Boston, USA & Art & 2011 \\
\hline $\begin{array}{l}\text { 2. Anthropocene } \\
\text { Single artist: Brendan Mcgillicuddy }\end{array}$ & Art Gallery of Alberta, Canada & Art & 2012 \\
\hline $\begin{array}{l}\text { 3. Expo1: New York } \\
\text { Several artists + Multiside shown }\end{array}$ & $\begin{array}{l}\text { MOMA, Queens, USA, and other } \\
\text { sites. }\end{array}$ & Art & 2013 \\
\hline $\begin{array}{l}\text { 4. The Anthropocene at HKW } \\
\text { Several artists + Multiside projects in several countries } \\
\text { since } 2013\end{array}$ & $\begin{array}{l}\text { Haus der Kulturen der Welt, Berlin, } \\
\text { Germany }\end{array}$ & Art & 2013 \\
\hline 5. Welcome to the Anthropocene & $\begin{array}{l}\text { Deutsches Museum; Munich, } \\
\text { Germany }\end{array}$ & $\begin{array}{l}\text { Museum of Science } \\
\text { and Technology }\end{array}$ & 2014 \\
\hline $\begin{array}{l}\text { 6. Ark of the Anthropocene } \\
\text { Single artist installation: Sean Connaughty }\end{array}$ & $\begin{array}{l}\text { Duluth, Lake Superior, USA } \\
\text { Duluth Art Institute (DAl) }\end{array}$ & Art & 2014 \\
\hline $\begin{array}{l}\text { 7. The Great Acceleration - Art in the Anthropocene } \\
\text { Several artists }\end{array}$ & Taipei Bienniale 2014, Taiwan & Art & 2014 \\
\hline $\begin{array}{l}\text { 8. A monument to the Anthropocene. } \\
\text { Several artists }\end{array}$ & Les Abbatoirs, Toulouse, France & Art & 2014 \\
\hline 9. Anthropocene & $\begin{array}{l}\text { Museo do Amanha (Museum of } \\
\text { Tomorrow), Rio de Janeiro, Brazil }\end{array}$ & $\begin{array}{l}\text { Applied Science } \\
\text { Museum }\end{array}$ & 2015 \\
\hline $\begin{array}{l}\text { 10. Placing the Golden Spike: Landscapes of the } \\
\text { Anthropocene } \\
\text { Several artists }\end{array}$ & $\begin{array}{l}\text { INOVA (Institute of Visual Arts), } \\
\text { Milwaukee, USA }\end{array}$ & Art & 2015 \\
\hline $\begin{array}{l}\text { 11. Dump! Making and unmaking } \\
\text { Several artists }\end{array}$ & Kunsthal Aarhus, Denmark & Art & 2015 \\
\hline $\begin{array}{l}\text { 12. A.N.T.H.R.O.P.O.C.E.N.E } \\
\text { Several artists }\end{array}$ & $\begin{array}{l}\text { Meessen De Clercq, Brussels, } \\
\text { Belgium }\end{array}$ & Art & 2015 \\
\hline $\begin{array}{l}\text { 13. Perpetual Uncertainty - Contemporary Art in the } \\
\text { Nuclear Anthropocene } \\
\text { Several artists } \\
\text { Several venues }\end{array}$ & $\begin{array}{l}\text { Several Venues: Bildmuseet, } \\
\text { Umeå, Sweden + Z33 House for } \\
\text { Contemporary Art, Hasselt, Belgium }\end{array}$ & Art & 2016 \\
\hline $\begin{array}{l}\text { 14. Future Perfect - Picturing the Anthropocene } \\
\text { Several artists }\end{array}$ & $\begin{array}{l}\text { University at Albany Art Museum, } \\
\text { Albany, USA }\end{array}$ & Art & 2016 \\
\hline $\begin{array}{l}\text { 15. Let's Talk About the Weather - Art and Ecology in a } \\
\text { Time of Crisis } \\
\text { Several artists } \\
\text { Several venues }\end{array}$ & $\begin{array}{l}\text { Several venues: Sursock Museum, } \\
\text { Beirut, Lebanon (2016) } \\
\text { Guangdong Times Museum, China } \\
\text { (2018) }\end{array}$ & Art & $\begin{array}{l}2016 \\
2018\end{array}$ \\
\hline 16. Anthropocene & $\begin{array}{l}\text { Ricardo Crespi, Art Gallery, Milan, } \\
\text { Italy }\end{array}$ & Art & 2016 \\
\hline 17. Mild Apocalypse & $\begin{array}{l}\text { Moesgaard Museum, Aarhus, } \\
\text { Denmark }\end{array}$ & $\begin{array}{l}\text { Cultural history/ } \\
\text { ethnography }\end{array}$ & 2016 \\
\hline $\begin{array}{l}\text { 18. The Anthropocene (2016 Thematic) } \\
\text { Several artists }\end{array}$ & $\begin{array}{l}\text { Roda Sten Konsthall, Gothenburg, } \\
\text { Sweden }\end{array}$ & Art & 2016 \\
\hline $\begin{array}{l}\text { 19. Body - Human of the Anthropocene - Program } \\
\text { within the European Capital of Culture } 2016\end{array}$ & Pokoyhof passage, Wroclaw, Poland & Art & 2016 \\
\hline 20. Objective Earth: Living in the Anthropocene & $\begin{array}{l}\text { Museum of Natural History, Sion, } \\
\text { Switzerland }\end{array}$ & Natural history & 2016 \\
\hline $\begin{array}{l}\text { 21. A scene from the Anthropocene } \\
\text { Single artist: Michael Arcega }\end{array}$ & $\begin{array}{l}\text { Linfield Gallery; Linfield College, } \\
\text { McMinnville, Oregon, USA }\end{array}$ & Art & 2016 \\
\hline 22. The Museum of the Anthropocene & $\begin{array}{l}\text { Museum of the Anthropocene, } \\
\text { Indianapolis, USA }\end{array}$ & $\begin{array}{l}\text { University project, } \\
\text { cultural history }\end{array}$ & 2016 \\
\hline $\begin{array}{l}\text { 23. A Stratigraphic Fiction } \\
\text { Several artists }\end{array}$ & $\begin{array}{l}\text { The Philip and Muriel Berman } \\
\text { Museum of Art, Collegeville, USA }\end{array}$ & Art & 2016 \\
\hline
\end{tabular}




\begin{tabular}{|c|c|c|c|}
\hline $\begin{array}{l}\text { 24. Anthropocene Markers } \\
\text { Several artists }\end{array}$ & $\begin{array}{l}\text { Likky Ruph, Art Gallery, Brooklyn, } \\
\text { USA }\end{array}$ & Art & 2016 \\
\hline $\begin{array}{l}\text { 25. Moving Plants } \\
\text { Several artists }\end{array}$ & Rønnebæksholm, Næstved, Denmark & Art & 2017 \\
\hline $\begin{array}{l}\text { 26. Anthropocene Island: the TAB } 2017 \text { curated } \\
\text { exhibition }\end{array}$ & $\begin{array}{l}\text { Estonian Museum of Architecture, } \\
\text { Tallinn, Estonia }\end{array}$ & Architecture & 2017 \\
\hline $\begin{array}{l}\text { 27. Survival Kit for the Anthropocene-Trailer } \\
\text { Single artist: Maja Smrekar }\end{array}$ & $\begin{array}{l}\text { Aksioma - Institute for Contemporary } \\
\text { Art, Ljubljana, Slovenia }\end{array}$ & Art & 2017 \\
\hline $\begin{array}{l}\text { 28. Natur-retur } \\
\text { Two artists: Nanna Debois Buhl \& Tue Greenfort }\end{array}$ & Arken, Ishøj, Denmark & Arts & 2017 \\
\hline $\begin{array}{l}\text { 29. In the Anthropocene } \\
\text { Several artists }\end{array}$ & Ocula, Wellington, New Zealand & Art & 2017 \\
\hline $\begin{array}{l}\text { 30. Anthropocene } \\
\text { Single artist: Arthur Apanski }\end{array}$ & Wollongon Art Gallery, Australia & Art & 2017 \\
\hline $\begin{array}{l}\text { 31. Birdland and the Anthropocene Exhibition } \\
\text { Several artists }\end{array}$ & $\begin{array}{l}\text { The Peale Center for Baltimore } \\
\text { History and Architecture, USA }\end{array}$ & Arts & 2017 \\
\hline $\begin{array}{l}\text { 32. Dreaming in the Anthropocene } \\
\text { Single artist: Chris Corson-Scott }\end{array}$ & $\begin{array}{l}\text { Trish Clark Gallery, Auckland, New } \\
\text { Zealand }\end{array}$ & Arts & 2017 \\
\hline 33. We are Nature - Living in the Anthropocene & $\begin{array}{l}\text { Carnegie Museum of Natural History, } \\
\text { Pittsburgh, USA }\end{array}$ & Natural history & 2017 \\
\hline 33.a Anthropocene in our Livingroom & $\begin{array}{l}\text { Carnegie Museum of Natural History, } \\
\text { Pittsburgh, USA }\end{array}$ & $\begin{array}{l}\text { Natural history + } \\
\text { art etc. }\end{array}$ & 2019 \\
\hline $\begin{array}{l}\text { 34. The Museum of the Anthropocene Technology } \\
\text { (whole museum, permanent thematic) } \\
\text { Several artists and scientists engaged }\end{array}$ & $\begin{array}{l}\text { The Museum of the Anthropocene } \\
\text { Technology, Laveno Mombello, Italy }\end{array}$ & Technology & 2018 \\
\hline $\begin{array}{l}\text { 35. Anthropocene } \\
\text { Several artists } \\
\text { Several venues }\end{array}$ & $\begin{array}{l}\text { Several venues: Art gallery of } \\
\text { Ontario, Toronto, + The National } \\
\text { Gallery of Canada Ottawa, Canada + } \\
\text { MAST. Bologna, Italy. }\end{array}$ & Arts & 2018 \\
\hline $\begin{array}{l}\text { 36. Down to Earth - Danish Painting 1780-1920 and } \\
\text { Landscapes of the Anthropocene }\end{array}$ & $\begin{array}{l}\text { Several venues: Faaborg Museum, } \\
\text { Fuglsang Kunstmuseum, Ribe } \\
\text { Kunstmuseum, The Hirschprung } \\
\text { Collection, Denmark }\end{array}$ & Arts & 2018 \\
\hline $\begin{array}{l}\text { 37. The World to Come - Art in the Age of the } \\
\text { Anthropocene } \\
\text { Several artists } \\
\text { Several venues }\end{array}$ & $\begin{array}{l}\text { Several venues: Harn Museum } \\
\text { of Art, Gainesville, Florida, USA } \\
\text { (2018), Museum of Art. University of } \\
\text { Michigan. USA (2019) }\end{array}$ & Art & $\begin{array}{l}2018- \\
2019\end{array}$ \\
\hline 38. Natura Naturans & $\begin{array}{l}\text { Washington Projects for the Arts, } \\
\text { Washington, USA }\end{array}$ & Art & 2019 \\
\hline $\begin{array}{l}\text { 39. Artropocene: The Artist in the Era of Social } \\
\text { Responsibility and Activism }\end{array}$ & $\begin{array}{l}\text { Y Center for Visual Arts, Honolulu, } \\
\text { Hawai'i, USA }\end{array}$ & Art & 2019 \\
\hline $\begin{array}{l}\text { 40. The Seventh Continent } \\
\text { Several artists }\end{array}$ & $\begin{array}{l}\text { 16th Istanbul Biennial, Istanbul, } \\
\text { Turkey }\end{array}$ & Art & 2019 \\
\hline $\begin{array}{l}\text { 41. The Post-Anthropocene } \\
\text { Single artist: Naoya Inose }\end{array}$ & $\begin{array}{l}\text { Daiwa Anglo-Japanese Foundation, } \\
\text { London, UK }\end{array}$ & Art & 2019 \\
\hline
\end{tabular}

\section{The Anthropocene in the Museum: Definitions, Methods, and Data}

In the following analysis, we distinguish between three types of museums where the Anthropocene has been exhibited and discussed as a subject: art museums, Cultural History museums (including Science, Technology, Ethnography and Architecture) and Natural History museums. Acknowledging that countries have different organizational structures for museums, we have chosen a broad definition that includes a range of art institutions which might not fit into the traditional definition of a museum or receive state subsidies according to museum responsibilities. Furthermore, we do appreciate the interdisciplinary nature of many exhibitions. 
The data used in the study is primarily extracted from museum homepages as well as relevant online exhibition catalogues. Wherever possible we have extracted information from journal articles about the exhibitions. Based on this thorough journal review and web-search, a total of 41 exhibitions, located at different types of museums and in different countries, emerge as having worked explicitly with the Anthropocene (see Appendix $1^{5}$ ). We have not been able to personally visit the 41 exhibitions and conduct elaborate analyses of their content, structures, media use and communicative forms. But based on the extraction of compelling information from homepages, catalogue texts and journal articles, the analysis follows three lines of inquiry. First, we take a general look at which museums and exhibitions have been occupied with the Anthropocene. Second, we investigate the stated purposes and aims of these exhibitions. Third, we account for the content and the various ways of projecting the Anthropocene among the exhibitions.

\section{Museum Exhibitions about the Anthropocene 2011-2019}

In 2011, the Anthropocene was put on exhibition for the first time by the American streetartist, Swoon, at the Institute of Contemporary Art (ICA) in Boston, USA. This exhibition, Anthropocene Extinction, combined philosophy and artistic sources of inspiration from around the globe in a critical assessment of the effects of industrialized society on people and the environment. Two other art institutions in North America (exh. 2, 3) staged exhibitions about the Anthropocene between 2011 and 2013. In 2013, the German art institution Haus Der Kulturen der Welt in Berlin followed suit with a large and multidisciplinary project, including several subprojects, which, by 2020 , are still ongoing. Also in Germany, in 2014, the first cultural history exhibition opened at the Deutsche Museum (Museum of Science and Technology, Munich). In 2016, The Museum of Natural History in Sion, Switzerland put on a major exhibition about the Anthropocene. Still, it is evident that art institutions, having organized 33 out of 41 exhibitions, have been far more occupied with the Anthropocene than the other museum types (see figure 2).

Art exhibitions include a variety of art forms such as painting, photography, sculptures, ready-made objects, videos, installations and ephemeral events. In the cultural history and natural history museums, media use likewise varies greatly from collection objects to installations, films, text-presentations and ready-made objects (exh. 17, 20). Some exhibitions seem to use similar display and ordering methods to other current exhibition topics (exh. 5, 9, 33). Others have deliberately re-contextualized collection objects (exh. 20, 33, 34) and some have applied alternative visual ways of displaying them (exh. 17, 20).

Geographically, as shown in figure 3, the museums exhibiting the Anthropocene are located in numerous different countries, including New Zealand, China, Lebanon, Sweden, and Turkey. However, most exhibitions were put on show in Western Countries, especially in the USA (15 out of 41). It is noticeable that Denmark, despite being a small country with a population under six million people, has had five exhibitions about the Anthropocene during the period 2011-2019. This is no doubt because the country's second-largest university has hosted the Aarhus University Research on the Anthropocene (AURA), an internationally acclaimed group of researchers including Anna Tsing, Nils Bubandt, Elaine Gan, Donna Haraway and Scott Gilbert, who are all highly involved in international academic debates about the Anthropocene. Several participants in the AURA project have curated museum exhibitions in Denmark about the Anthropocene and, more indirectly, the group has successfully inspired other museums to join the conversation.

\section{Stated Purposes and Aims of the Exhibitions about the Anthropocene}

The most prevalent common characteristic of the 41 exhibitions about the Anthropocene is that they maintain a clearly explorative approach to their topic. Hence, many exhibitions have as their main purpose the investigation of questions such as: What does it mean to exist in an epoch dominated by humans? ${ }^{6}$ (exh. 18); when and where did human activity begin to leave its indelible mark upon the surface of Earth? ${ }^{7}$ (exh. 10); what implication does it have for policy and for the prospects of global action considering that we in the Global North are often shielded from the worst effects of anthropogenic changes to the planet, and tend only 
to experience the 'mild' dimensions of the Anthropocene? (Brichet and Hastrup 2019, exh. 17 ); or what resources and protective mechanisms does humanity have to cope with this new epoch? ${ }^{8}$ (exh. 12).

\section{EXHIBITIONS ON THE ANTHROPOCENE BY MUSEUM/VENUE TYPE: 2011- 2019}

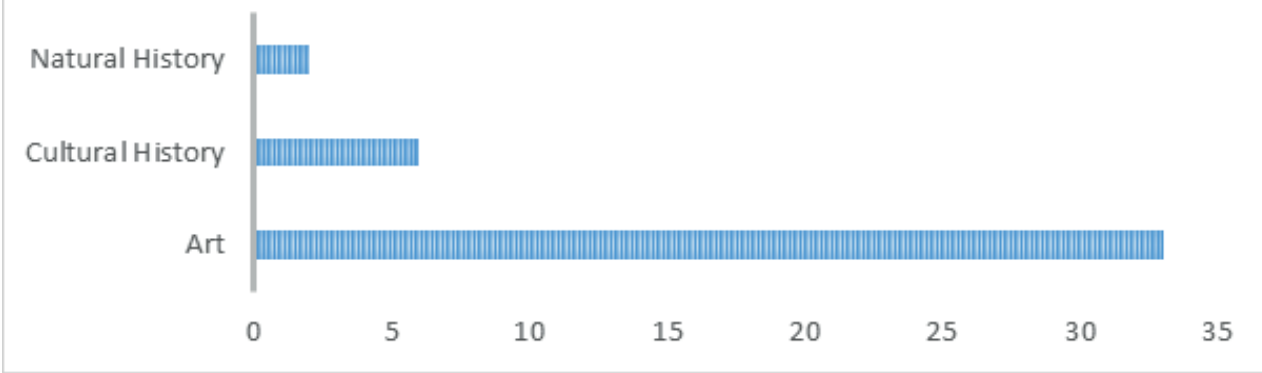

Figure 2: Exhibitions on the Anthropocene by museum/venue type, 2011 - 2019

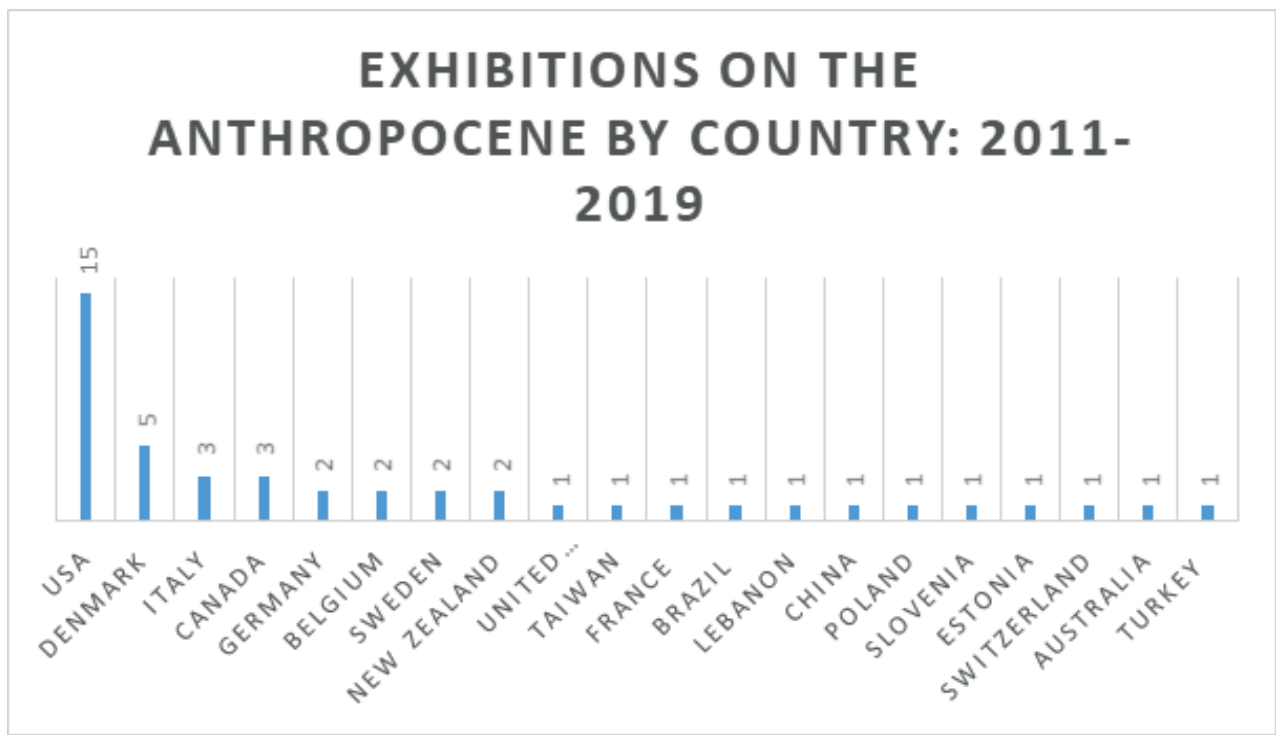

Figure 3: Exhibitions of the Anthropocene by country, 2011 - 2019

Note: The total amounts to 46 exhibitions, as five exhibitions are re-settings of the exhibitions. Several re-settings appear across countries, e.g. an exhibition from Canada goes to Italy, an exhibition from Lebanon goes to China. In order to display the geographic variances of museum communication on the Anthropocene these re-settings are included in the diagram. 
A small minority among the exhibitions (exh. 6, 10, both arts) sets out to create solutions to the climate and extinction crisis. In one case (exh. 6) this is done by constructing an Ark containing 'an assortment of growing plants, soil, organic matter and a time capsule filled with seeds and other artifacts of life on Earth'. ${ }^{9}$ The other case (exh. 10) initiates an urban greening project as a 'small-scale, high-impact solution to create more biodiversity in mono-cultural urban environments and remediate ecological change'. ${ }^{10}$ Still, rather than presenting the Anthropocene as a problem to be resolved, the general tendency in the 41 exhibitions is to give a presentation that invites audiences to learn and reflect about this new concept and become personally engaged with it one way or the other. Exhibiting on the Anthropocene thereby involves open questions, uncertainty and the lack of settled truths, and museums are aware of the fact that their audiences are unlikely to be familiar with the idea of the Anthropocene or, for that matter, convinced of the relevance of the issue. The two pioneering European projects at Deutsche Museum and Haus Der Kulturen der Welt conducted preliminary audience research in order to get insights into the general public's knowledge about the Anthropocene. In both cases, it was found that recognition was low (Bauerlein and Förg 2012). Both projects therefore had as their aims, respectively, to make the idea of the Anthropocene 'accessible and relevant for a general audience' (Robin et al. 2014: 214, exh. 4) and 'to let visitors experience the Anthropocene and learn about the current state of scientific knowledge and debate' (Robin et al. 2014: 212, exh. 5). Both institutions also had the aim of igniting participation among visitors.

The relationship between museums and their audiences is an issue often emphasized in the gathered material. Exhibition aims are presented as, for example: 'to encourage visitors to reflect on the Anthropocene Era and their own role as part of human action and its transforming power'11 (exh. 9). In addition to this, several museums highlight their exemplary potential to be public platforms for discussions, conversations and connections across different professional disciplines and across museums and audiences. Finally, the aim of spurring the public to take action on the crisis is an explicit vision of several exhibitions (e.g. exh. 9, 20, 33, 35).

Numerous museums raise fundamental questions such as: 'What does it mean to make art in the age of the Anthropocene?'12 (exh. 29), and 'Can collections of things still [...] be an instrument to define new categories and better understand our times?'13 (exh. 34). Both artworks and collections of objects, it is suggested, have a certain capacity to motivate audiences to understand as well as act in a time of crisis. Art is perceived to 'initiate novel connections and dynamic conversations'14 (exh. 15) and create 'new ways of seeing and thinking about the world to come'15 (exh. 37). The natural historic and scientific objects are perceived to 'raise marvel and doubt and contribute to a new culture, with categories that are less theoretical and more terrestrial, more real and more shared"16 (exh. 34).

\section{Content, Messages and the Approach to the Anthropocene}

Three particularly noteworthy trends emerge from our source material in regard to the content and the approach to the Anthropocene taken in the exhibitions. First, in every exhibition the Anthropocene is linked with other concepts and phenomena in clusters of meanings, as is typical of keywords. The composition of these clusters, however, varies considerably among the exhibitions. Second, similarly to the scientific literature about the Anthropocene, the exhibitions differ significantly in terms of how they delimit the Anthropocene in time. Third, as already mentioned, most exhibitions include a reflective part that addresses the role of museums in an Anthropocene world, as well as the role of the audience and their lifestyles and consumption practices in this epoch.

In the surveyed exhibitions, the Anthropocene is clustered with a wide range of other topics that include: Human-nature relations, weather and climate change, pollution, industry, mining and quarrying, rivers/waterways, fossil fuels, nuclear activity, waste, technology and the digital, data-streams, consumption, human-machine interactions, oil extraction, technology, urbanization, justice, mobility, nutrition, evolution, birds, plants, the human body etc. In the Natural History and Cultural History exhibitions (e.g. exh. 5, 9, 33, 34) the tendency to link the Anthropocene with several different sub-topics such as pollution, extinction, habitat alteration, human-nature transformations (exh. 35) or very broad notions such as Man's impact on 
Earth (exh. 9) is particularly prevalent. However, a few exhibitions about the Anthropocene concentrate in depth on just one related sub-topic such as birds (exh. 31), plants (exh. 25), geology and sediments (exh. 23), human-nature landscapes (exh. 26), radioactivity (exh. 27) or the Mississippi River (exh. 4).

One Lebanese exhibition emphasized the Anthropocene as a consequence of postcolonial structures rather than individual human actions. This exhibition explicitly illuminated 'the intersection of western jurisprudence and the indigenous conception of nature'19 (exh. 15 ) through artwork that displayed different ways of understanding the sun (as God or as a natural resource). Thus, the artistic expressions of this exhibition raised questions about global inequity and multiple human-nature connections across the globe in a similar way to several critical writers in the academic world (Malm and Hornborg 2014; Nixon 2014; Baskin 2015; Swanson et al. 2015; Haraway et al. 2016; Moore 2016; Tsing et al. 2017; Davis et al. 2019).

While the premise of most exhibitions is that the Anthropocene represents a new epoch in the history of planet Earth, the exact definition of the Anthropocene from a historical perspective varies from one exhibition to the other regardless of country and museum type. Most exhibitions contain a historical narrative of accelerated human use of and impact on nature over time. For example, one cultural history museum describes the era of industrialization with specific emphasis on resource management, exploitation and consequences (exh. 5). An art museum describes artists' perceptions and expressions of dramatic transformations of farming landscapes in the last 200 years (exh. 36). A natural history museum uses collection objects to portray the histories of pollution, extinction and habitat alteration (exh. 33). These exhibitions tell a story of historical change towards ever-increasing human dominance and destruction of the natural world.

However, other historical narratives are found as well. One art exhibition (exh. 10) invited several artists to reflect on the beginning of the Anthropocene and the works of these artists suggested quite differing starting points, such as the beginning of intercontinental trade, the onset of the industrial revolution and large-scale fossil fuel extraction, the advent of nuclear testing, and the invention of agriculture over 40,000 years ago. Another art exhibition (exh. 32) displayed photographs of historical remnants of industrial behemoths and trade in New Zealand such as industrial sites and shipwrecks. These remnants were largely decayed and forgotten by the public. Nature had taken over, so to speak. The online material for this exhibition explained that 'the photographs parallel the velocity of nature with that of factory production'. ${ }^{17}$ The time perspective found in these exhibitions somehow challenges, or even reverses, the historical narrative that dominate the above-mentioned exhibitions, in part by stressing that nature, though subdued in the Anthropocene era, is still forceful and perhaps ultimately beyond human control. Along the same vein, though without an explicit historical perspective, an Estonian architecture exhibition (exh. 26) presented cities from the satellite view and the micro scale in order to challenge the 'customary human (Anthropos) view'18 that separates the natural from the artificial.

The need to challenge the era of Enlightenment's ontological divide between nature and culture, the natural and the artificial, appears to be a key motivation for all the reviewed exhibitions. This challenge remains at the core of most museums' vision of their own role as museums in an Anthropocene world and of their attempt to get audiences to reflect upon their lifestyles and consumption practices in this epoch.

Some exhibitions take collection objects into new contexts, playing with shifting their ontologies between nature and culture (e.g. exh. 11, 17, 20,25), authenticity and reconstruction (exh. 17). In this way both art and collection objects are seen as pointing towards new ways of understanding and relating to the world that can challenge well-established schemes of thinking and acting that we live with today, for instance consumerism, the ideal of growth and human-nature relations of Modernity.

In one Danish exhibition in a cultural history museum (exh. 17) the fairytale figure Goldilocks was introduced as an analytical figure to represent the audience. Several installations in the exhibition were constructed in order for the audiences to reflect on their own role in relation to the Anthropocene landscape, mainly by asking questions as to how humans can at once stay in contact with nature and be human, be curious and confident, strangers and at home, humble and exploring (like Goldilocks). By emphasizing these ambivalent positions, 
the exhibition suggested a new human politics for establishing connections to other species and enabling an ontological shift away from the ideas of human control associated with 'a long lost Enlightenment Dream' (Brichet and Hastrup 2019: 129).

Several art exhibitions (exh. 2, 7, 8, 9, 12, 19, 25) have purposely displayed the human position and self-perception in relation to nature: Debating the transforming power of humans (exh. 9), new contracts between humans and animals, vegetals etc. (exh.7), new approaches and beliefs (such as political ecology, exh. 8), our conflicted relationship to the natural world (exh. 14) and also how populism, authoritarianism, and ethnic tribalism (exh. 29), as well as consumer culture (exh. 31), assist in accelerating the Anthropocene footprints. These exhibitions thus address their audiences as co-actors, co-responsible for the current planetary and human predicament, and as potential initiators of transformation towards a better balance. They encourage audiences to monitor themselves as humans and reflect on their responsibilities as members of the human species. However, only very few exhibitions concretize what such responsibilities and transformations should consist of. The urban greening project (exh. 10) mentioned earlier is an example of an exhibition where action and collaboration with the public is combined. In a quite different manner, the Lebanese art museum (exh. 15) took action by encouraging artist and technicians to use only local and re-used materials when producing the exhibition. This museum also set up a measuring system to pre-calculate rates of energyuse and waste disposal in relation to setting up the exhibition and used these calculations to influence decision making in the process of making the exhibition.

\section{Discussion: Inclusive or Exclusive Connectivity in the Anthropocene}

The Anthropocene in the museum displays all the characteristics that Raymond Williams (1976) and Bennett et al. (2005) associate with keywords. In the museum, as in the scientific literature, the Anthropocene is used to 'discuss central processes' of our common life. The general tendency of museums to approach the Anthropocene as an uncertain, questionable and scientifically unsettled truth lends an openness and lack of precision to the topic, which is well-known from the history of other keywords as well. The Anthropocene appears in a variety of clusters with other topics such as climate change, ecological crisis, industrialization, pollution, nuclear radiation, eurocentrism and colonization. Indeed, Pórsson's review of the Welcome to the Anthropocene exhibition in Munich shows that this singular exhibition in itself presents three different versions of the Anthropocene - as history, as a spatially explored phenomenon, and as 'a tool to catch slippages' (Pórsson 2020: 116). The multitude of meanings and relationships attached to the Anthropocene in the museum demonstrates the complex nature of the term.

In the museum, the Anthropocene furthermore appears to be treated as heritage in the sense of 'transformable practices' (Harrison 2015: 34) and, perhaps more accurately, as practices 'fundamentally concerned with assembling and designing the future' (Harrison 2015: 35). Rather than a well-defined issue, the Anthropocene is displayed as a concept in motion and, we would like to argue, as the ultimate keyword in the sense of being a notion under permanent collective investigation and exposed to 'conscious changes, or consciously different uses' (cf. Williams 1976: 17). In this way, the exhibitions in many ways mirror the discourse about the Anthropocene that we find within academia. However, in the museum, the communication of the concept attempts to appeal to both sense and sensibility by presenting complex factual accounts as well as highly emotional and identifiable questions and reflections. Also, most exhibitions seek to reserve space for reflection, revision and change in the understanding of the Anthropocene that they present to the public.

With the goal of engaging audiences in debates about the Anthropocene epoch and with the explicit hope of engaging audiences actively with their common heritage, the museums provide public platforms for discussion and present themselves as catalysts for action and change towards a more sustainable future.

The Anthropocene seems chosen to 'remake both ourselves and the world in the present, in anticipation of an outcome that will help constitute a specific (social, economic, or ecological) resource in and for the future' (Harrison 2015: 35). Arguably, the museums with this approach to the Anthropocene heritage seek to fulfil their responsibility towards their 
surrounding societies. This mobilization of exhibition spaces as a form of 'future assembling practice' (cf. Harrison 2015) and the presentation of a notion of heritage where change is regarded 'as equally important as stasis' (Harrison 2015: 33) is a far cry from other heritage representations of the past.

The dialogical model of heritage found in most of the exhibitions about the Anthropocene encourages audiences to think about the past and future not only of their own species but also of other non-human actors. By clustering plants, animals, minerals, art objects, technology and human beings into concrete exhibits and narratives, the museums seem to work with some sense of 'connectivity ontologies' (cf. Rose and Robin 2004; Harrison 2015; Hodgetts 2017); for example, when questioning modernity's nature-culture dichotomy by combining objects and subjects that are conventionally seen as belonging to different spheres. Cultivating potatoes in an art gallery (exh. 11) is a case in point. By clustering objects and subjects from what used to be considered different realms of being into their Anthropocene exhibitions, the museums seek to establish a new sense of reality, or what Harrison (2015: 33) calls a 'flat notion of the social'; that is, a notion that implies that all 'being' is interactive and is part of the same broader 'natural-cultural assemblage' (Harrison 2015: 33; see also Bateson 1972: 436; Latour 2004).

But how 'flat' are the exhibitions in the ways they portray natural-cultural assemblages in the Anthropocene? And to what extent do the exhibitions question the position of human beings vis-à-vis non-human actors? In general, the human position in the exhibitions is defined as either 'villain' (the white industrial colonizer of nature) or 'potential saviour' (the white scientist/technological innovator). More thorough reflections regarding the specificities of the human subject in the Anthropocene are absent except for very few exhibitions such as the one curated by Hastrup and Brichet (exh. 17) described above. The museums are curiously silent or, as exemplified in exh. 10, nearly silent in regard to the dating and naming of the Anthropocene. But as Baldwin and Erickson contend, 'the Anthropocene is a geohistorical event, the stratigraphic signature of which cannot be easily decoupled from the histories of race and racism, capitalism, and European imperialism' (Baldwin and Erickson 2020: 4). In their view, the backdating of the Anthropocene by some researchers to the beginning of the Neolithic period implies a denial of the culpability of modern industrialized Western societies in causing planetary climate change and environmental destruction. Likewise, the very term Anthropocene as it is employed by e.g. Crutzen and Stoermer (2000) signifies the will to reject that actions and decisions made by a small elite of mostly Western white people is the cause of a globally felt climate crisis. As argued by Lowe, 'When the category of the Anthropos is assumed to be universal, it repeats the 'liberal forgetting' of modernity as a racial project built upon the affirmation of white progress' (Lowe, cited in Baldwin and Erickson 2020: 5).

Few museums seem to be aware of this view in their exhibitions about the Anthropocene. Instead of being specific about the culprits and reasons behind the environmental crisis, the majority of exhibitions use words such as human and humanity to signal a universally shared origin of the crisis. Exceptions to this trend are the Lebanese exhibition (exh. 15) of the Anthropocene seen from a post-colonial standpoint, and the artworks that thematize indigenous and local cultures (exh. 21), as well as their regrettable disappearance in the grip of neoliberal economics (exh. 25). Quite symptomatically, Pórsson's review of the Deutsche Museum's Welcome to the Anthropocene finds that the part of the exhibition that was specifically designed to spur 'freestyle conversation' and highlight the 'uneven interplay of heterogeneous material-semiotic actors' was not featured substantially in the exhibition as a whole (Pórsson 2020: 114). In fact, the exhibitions overviewed in this paper mostly bypass these controversial topics when describing their aims and strategies of dealing with the Anthropocene.

It is puzzling why the museums ignore or underplay these debates. Why do they not introduce to their audiences some of the alternative, and possibly more accurate, terms such as 'Capitolocene' (Malm and Hornborg 2014), 'Plantationocene' (Haraway 2015), 'Racial Capitolocene' (Verges 2017), or even 'White-supremacy-cene' (Mirzoeff 2018)? Instead, the exhibitions put on show an Anthropocene and a 'future-assembling' that deliberately exclude the controversies about both the concept and the predicament of the world from their arenas for reflection. 
By emphasizing a fascination with overcoming modernity's nature-culture dichotomy, the museums generally tend to ignore the voices of indigenous scholars and artists from around the world for whom this is something that non-Western peoples have always known (Horton and Horton 2017; Tallbear and Willey 2019). In this way, by not acknowledging the ontologies, philosophies and cultural histories of non-Western people, the Anthropocene in the museum is at risk of becoming a colonizing concept that should be rejected (cf. Todd 2015).

It may be useful at this point to recall that Raymond Williams's interest in keywords implied a notable measure of ambiguity towards these words. On the one hand, he stressed the importance of language, including the keywords, as a site or medium of social and historical change because language may bring out new kinds of meanings and ways of seeing the world. On the other hand, he stated that:

'I do not share the optimism [...] that clarification of difficult words would help in the resolution of disputes conducted in their terms and often evidently confused by them. I believe that to understand the complexities of the meanings of class contributes very little to the resolution of actual class disputes and class struggles' (Williams 1976).

Still, understandings are important, too. How museums understand and conceptualize topics in their exhibitions are vital for their public legitimacy and for their ability to stir up conversations with their audiences. Considering the significant controversies inherent in the concept of the Anthropocene, it is fair to ask whether exhibiting the Anthropocene might, paradoxically, mean a missed opportunity to create the conversations which the museums apparently intend to create. The very concept of the Anthropocene carries the dilemma that it focuses peoples' attention on something that needs urgent attention; it is available in language, so to speak, and in the cultural imagination of many people and, yet, it absolutely needs to be 'complicated', as mentioned earlier by Donna Haraway (Haraway and Kenney 2015: 259). By downplaying the controversies of the Anthropocene, many exhibitions dealt with in our analysis do not appear to have opted for what we believe is the right conversations about this topic but, rather, perhaps simply the conversations that were deemed possible to have. If the concept of the Anthropocene, as critics argue, implies a large degree of whitewashing of historical inequality and exploitation, museums may inadvertently exacerbate the very problems addressed in the exhibitions by choosing to communicate with their audiences through this term. Or, maybe, the high aspirations behind exhibitions about the Anthropocene are met in the sense that the museums have managed to start a vital conversation in the public domain that would otherwise have been confined to scientific debates. In any case, exhibiting the Anthropocene is clearly not just a matter of public understanding of science because, as a keyword, the Anthropocene is so much more than a scientific concept. Recalling Bennett et al.'s intentional inclusion of diverging voices in the author collective responsible for their volume of revised keywords (2005), it is tempting to conclude that several exhibitions reviewed in this paper would have benefitted from a similar commitment to include controversy and deeper clarification of the meanings of the Anthropocene.

Received: 3 July 2020

Finally accepted: 16 February 2021

\section{Acknowledgements}

We appreciate the helpful comments by two anonymous reviewers and we are grateful for the collaborative spirit of our colleagues from the research and museum development project, 'The Cultural History of Northwestern Jutland (Denmark) as an Ethnobotanic Study'. The Velux Foundation has generously funded this project.

\section{Notes}

1 ICOM Definition of a Museum, http://archives.icom.museum/definition.html, accessed 6 January 2021. 
2 Instigating the public understanding of science has also been a central activity for many science museums. However, as the majority of exhibitions found in this study are not from science museums and as the concept does not seem to have a broad use in relation to other museum types, this concept was not implied to frame our study.

3 David Cope, Gardens of the Anthropocene', Inside Ecology, 6 April 2018. https:// insideecology.com/2018/04/06/gardens-of-the-anthropocenel, accessed 6 December 2020.

4 Caspar A. Hallmann, Martin Sorg, Eelke Jongejans, Henk Siepel, Nick Hofland, Heinz Schwan, Werner Stenmans, Andreas Müller, Hubert Sumser, Thomas Hörren, Dave Goulson, D. and Hans de Kroon, 'More Than 75 Percent Decline Over 27 Years in Total Flying Insect Biomass in Protected Areas', Plos One, 18 October 2017. https://doi. org/10.1371/journal.pone.0185809, accessed 6 January 2021.

5 https://vbn.aau.dk/admin/files/405561338/Appendix_1_OJS_.pdf

6 Roda Sten Konsthall, 2016 Thematic: The Anthropocene Gothenburg, Sweden. [section of gallery homepage], 2016. http://rodastenkonsthall.se/index.php/rs events/view/ anthropocene, accessed 6 January 2021.

7 INOVA(Institute of Visual Arts), 'Placing the Golden Spike: Landscapes of the Anthropocene', Milwaukee, USA [online catalogue], 2015. https://monoskop.org/images/8/81/Placing the Golden Spike Landscapes of the Anthropocene 2015.pdf, accessed 6 January $\underline{2021 .}$

8 Meessen De Clercq, A.N.T.H.R.O.P.O.C.E.N.E., Brussels, Belgium [section of gallery homepage], 2015. http://www.meessendeclercq.be/exhibitions/future/2015/anthropocene// P12l, accessed 6 January 2021.

9 Sheila Regan, 'An Artist's Ark Meets Its Fate on Lake Superior', Hyperallergic, 11 September 2014. https://hyperallergic.com/148275/an-artists-ark-meets-its-fate-on-lake-superior/, accessed 6 January 2021.

10 INOVA, 'Placing the Golden Spike'.

11 Museo do Amanha (Museum of Tomorrow), 'Possibilities for Building the Future', [section of museum homepage], Rio de Janeiro, Brazil, 2015. https://museudoamanha.org.br/en/ exhibitions, accessed 6 January 2021.

12 Lachlan Taylor, 'In the Anthropocene' [online published press release], 2017. https:// ocula.com/art-galleries/bartley-company-art/exhibitions/in-the-anthropocene/, accessed 6 January 2021.

13 Frank Raes, 'The Museum of Anthropocene', Tedxlakecomo [tedtalk published online], 2017. http://website.museumofanthropocenetechnology.org/2017-tedxlakecomo, accessed 6 January 2021.

14 Dutch Art Institute, '14 July to 17 October, Sursock Museum: Let's Talk About the Weather: Art and Ecology in a Time of Crisis Curated by Nataša Petrešin-Bachelez and Nora Razian', [online art forum], 2016. https://dutchartinstitute.eu/page/8728/14-july-to-17october-sursock-museum-let-s-talk-about-the-weather-art-and-eco, accessed 6 January $\underline{2021 .}$

15 Harn Museum of Art, 'The World to Come: Art in the Age of the Anthropocene, Gainesville, Florida, USA', [section of museum homepage], 2018. http://www.harn.ufl. edu/theworldtocome, accessed 6 January 2021. 
16 Raes, 'The Museum of Anthropocene'.

17 Nora Razian and Nataša Petrešin Bachelez, 'Art in the Time of the Anthropocene: Nora Razian, Nataša Petrešin Bachelez, and Angela Harutyunyan in conversation, with a contribution from Natasha Gasparian', IBRAAZ (Contemporary Visual Culture in North Africa and The Middle East), [online published conversation], 2016. https://www.ibraaz. org/interviews/196, accessed 6 January 2021.

18 Trish Clark Gallery, 'Chris Corson-Scott. Dreaming in the Anthropocene', Auckland, New Zealand [section of gallery homepage], 2017. https://trishclark.co.nz/exhibitions/chriscorson-scott-photographs-south-island/, accessed 6 January 2021.

19 Estonian Museum of Architecture, 'Anthropocene Island: the TAB 2017 curated exhibition' [section of museum homepage], 2017. https://arhitektuurimuuseum.ee/en/naitus/ anthropocene-island-the-tab-2017-curated-exhibition/, accessed 6 January 2021.

\section{References}

Autin, W. and Holbrook, J. (2012) 'Is the Anthropocene an Issue of Stratigraphy or Pop Culture?', GSA Today, 22, 60-1.

Baldwin, A. and Erickson, B. (2020) 'Introduction: Whiteness, Coloniality, and the Anthropocene', Environment and Planning D: Society and Space, 38 (1) 3-11.

Baskin, J. (2015) 'Paradigm Dressed as Epoch: The Ideology of the Anthropocene', Environmental Values, 24 9-22.

Bateson, G. (1972) Steps to An Ecology of Mind: Collected Essays in Anthropology, Psychiatry, Evolution and Epistemology, Northvale: Jason Armson.

Bäuerlein, H. and Förg, S. (2012) Vorab-Evaluation zur Sonderausstellung 'AnthropozänNatur und Technik im Menschenzeitalter, August-September, Internal Report. Munich: Deutsches Museum.

Bennett, T., Grossberg, M. and Morris, M. (2005) New Keywords: A Revised Vocabulary of Culture, Oxford: Blackwell Publishing.

BGCl (Botanic Gardens Conservation International) (2010) Towards a New Social Purpose: Redefining the Role of Botanic Gardens, Richmond: Botanic Gardens Conservation International.

Brichet, N.S. and Hastrup, F. (2019) 'Curating a Mild Apocalypse: Researching Anthropocene Ecologies through Analytical Figures', in Malene Vest Hansen, Anne Folke Henningsen and Anne Gregersen (eds) Curatorial Challenges: Interdisciplinary Perspectives on Contemporary Curating, 120-32, London: Routledge.

Cameron, F. and Kelly, L. (eds) (2010) Hot Topics, Public Culture, Museums, Newcastleupon-Tyne: Cambridge Scholars Publishing.

Cannon, C.H. and Kua, C.S. (2017) 'Botanic Gardens Should Lead the Way to Create a "Garden Earth" in the Anthropocene', Plant Diversity, 39 (6) 331-7.

Ceballos, C., Erhlich, P.R. and Dirzo, R. (2017) 'Biological Annihilation via the Ongoing Sixth Mass Extinction Signaled by Vertebrate Population Losses and Declines', Proceedings of the National Academy of Sciences of the United States of America (PNAS), 114 (30). 
Chakrabarty, D. (2009) 'The Climate of History: Four Theses', Critical Inquiry, 35 (2) 197222.

(2015) 'The Anthropocene and the Convergence of Histories', in Clive Hamilton, Christophe Bonneuil and François Gemenne (eds) The Anthropocene and the Global Environmental Crisis: Rethinking Modernity in a New Epoch, 44-56, London: Routledge.

Chynoweth, A., Lynch, B., Petersen, K. and Smed, S. (eds) (2020) Museums and Social Change: Challenging the Unhelpful Museum, London: Routledge.

Crossland, Z. (2014) 'Anthropocene: Locating Agency, Imagining the Future', Journal of Contemporary Archaeology, 1, 123-8.

Crutzen, P.J. (2002) 'Geology of Mankind’, Nature, 415 (23) 211-5.

Crutzen, P.J. and Stoermer, E.F. (2000) 'The Anthropocene', IGBP Newsletter, 41 (12) 138.

Davis, H. and Turpin, E. (eds) (2015) Art in the Anthropocene: Encounters Among Aesthetics, Politics, Environments and Epistemologies, London: Open Humanities Press.

Davis, J., Moulton, A.A., Sant, L.V. and Williams, B. (2019) 'Anthropocene, Capitalocene, Plantationocene?: A Manifesto for Ecological Justice in an Age of Global Crises', Geography Compass, 13 (5).

Davison, A. (2008) 'Ruling the Future? Heretical Reflections on Technology and Other Secular Religions of Sustainability', Worldviews: Global Religions, Culture, and Ecology, 12, 146-62.

(2015) 'Beyond the Mirrored Horizon: Modern Ontology and Amodern Possibilities in the Anthropocene', Geographical Research, 53 (3) 298-305.

Dunn, C.P. (2017) 'Biological and Cultural Diversity in the Context of Botanic Garden Conservation Strategies', Plant Diversity, 39, 396-401.

Einsiedel Jr., A.A. and Einsiedel, E.F. (2004) 'Museums as Agora: Diversifying Approaches to Engaging Publics in Research', in David Chittenden, Graham Farmelo and Bruce V. Lewenstein (eds) Creating Connections: Museums and the Public Understanding of Current Research, 73-86, Walnut Creek: Rowman Altamira.

Goodnow, K.J. and Akman, H. (eds) (2008) Scandinavian Museums and Cultural Diversity, New York: Berghahn Books.

Gurian, E.H. (2006) Civilizing the Museum: The Collected Writings of Elaine Heumann Gurian, London: Routledge.

Haraway, D. (2015) 'Anthropocene, Capitalocene, Plantationocene, Chthulucene: Making Kin', Environmental Humanities, 6, 159-65 www.environmentalhumanities.org ISSN: 2201-1919.

Haraway, D. and Kenney, M. (2015) 'Anthropocene, Capitalocene, Chthulucene. Donna Haraway in conversation with Martha Kenney', in Heather Davis and Etienne Turpin (eds) Art in the Anthropocene: Encounters Among Aesthetics, Politics, Environments and Epistemologies, 255-70, London: Open Humanities Press. 
Haraway, D., Ishikawa N., Scott, F., Gilbert, K., Olwig, A. L., Tsing, A. and Bubandt, N. (2016) 'Anthropologists Are Talking - About The Anthropocene', Ethnos, 81 (3) 53564.

Harrison, R. (2015) 'Beyond "Natural" and "Cultural" Heritage: Toward an Ontological Politics of Heritage in the Age of Anthropocene', Heritage \& Society, 8 (1) 24-42.

Heywood, V.H. (2017) 'Plant Conservation in the Anthropocene - Challenges and Future Prospects', Plant Diversity, 39 (6) 314-30.

Hodgetts, T. (2017) 'Connectivity', Environmental Humanities 9 (2) 456-59.

Horton, J. and Horton, L. (2017) 'Indigenous Artists against the Anthropocene', Art Journal, 76 (2) 48-69. DOI: 10.1080/00043249.2017.1367192.

Janes, R.R. and Sandell, R. (eds) (2019) Museum Activism, London: Routledge.

Kolbert, E. (2015) The Sixth Extinction: An Unnatural History, New York: Henry Holt.

Kreps, C. (2015) 'Appropriate Museology and the "New Museum Ethics". Honoring Diversity', Nordisk Museologi, 2.

Lane, P.J. (2015) 'Archaeology in the Age of the Anthropocene: A Critical Assessment of its Scope and Societal Contributions', Journal of Field Archaeology, 40 (5) 485-98.

Latour, B. (2004) Politics of Nature: How to Bring the Sciences into Democracy, Cambridge, MA: Harvard University Press.

Lorimer, J. (2011) 'Multinatural Geographies for the Anthropocene', Progress in Human Geography, 36 (5) 1-20.

Lundershausen, J. (2018) 'The Anthropocene Working Group and its (Inter-) Disciplinarity', Sustainability: Science, Practice and Policy, 14 (1) 31-45. DOI: 10.1080/15487733.2018.1541682.

Lynch, B. (2013) 'Reflective Debate, Radical Transparency and Trust in the Museum', Museum Management and Curatorship, 28 (1) 1-13.

Macalik, J., Fraser, J. and McKinley, K. (2015) 'Introduction to the Special Issue: Discursive Space', Curator: The Museum Journal, 58 (1) 1-3.

Macdonald, S. (2013) Memorylands: Heritage and Identity in Europe Today, London: Routledge.

Malm, A. and Hornborg, A. (2014) 'The Geology of Mankind? A Critique of the Anthropocene Narrative', The Anthropocene Review, 1 (1) 62-9.

Meyer, M. (2010) 'Caring for Weak Ties - The Natural History Museum as a Place of Encounter between Amateur and Professional Science,' Sociological Research Online, 15 (2) 133-46.

Mirzoeff, N. (2018) 'It's Not The Anthropocene. It's The White Supremacy Scene; or The Geological Colour Line', in Richard Grusin (ed) After Extinction, 123-49, Minneapolis, MN: University of Minnesota Press.

Moore, J.W. (2016) 'Anthropocene or Capitalocene? Nature, History, and the Crisis of Capitalism', Sociology Faculty Scholarship, 1. 
Newell, J., Robin, L. and Wehner, K. (eds) (2016). Curating the Future: Museums, Communities and Climate Change, Abingdon: Taylor \& Francis.

Nixon, R. (2014) 'The Anthropocene: The Promise and Pitfalls of an Epochal Idea', Edge Effects, 6.

Ogg, J. (2004) 'Status of Divisions of the International Geologic Time Scale', Lethaia, 37 (2) $183-99$.

Pórsson, B. (2020) 'Walking through the Anthropocene. Encountering Materialisations of the Geological Epoch in an Exhibition Space', Nordic Museology, 20 (1) 103-19.

Robin, L., Avango, D., Keogh, L., Möllers, N., Scherer, B. and Trischler, H. (2014) 'Three Galleries of the Anthropocene', The Anthropocene Review, 1 (3) 207-24.

Rose, D.B. and Robin, L. (2004) 'The Ecological Humanities in Action: An Invitation', Australian Humanities Review, 31 (2) australianhumanreview.org.

Rosenzweig, M.L. (2001) 'The Four Questions: What does the Introduction of Exotic Species do to Diversity?', Evolutionary Ecology Research, 3 361-7.

Royal Botanic Gardens Kew (RBG Kew) (2016) The State of the World's Plants Report 2016, London: Royal Botanic Gardens, Kew.

Ruddiman, W.F. (2003) 'The Anthropogenic Greenhouse Era Began Thousands of Years Ago', Climatic Change, 61 261-93.

(2013) 'The Anthropocene', Annual Review of Earth and Planetary Sciences, 41 45-68.

Rull, V. (2013) 'A Futurist Perspective on the Anthropocene', The Holocene, 23 1198-201.

Salazar, J.F. (2011) 'The Mediations of Climate Change: Museums as Citizens' Media', Museum and Society, 9 (2) 123-35.

(2014) 'Futuring Global Change in Science Museums and Centers: A Role for Anticipatory Practices and Imaginative Acts', in Fiona R. Cameron and Brett Neilson (eds) Climate Change and Museum Futures, 102-20, London: Routledge.

Sandahl, J. (2019) 'The Museum Definition as the Backbone of Museums', Museum International, 71 1-2, DOI: 10.1080/13500775.2019.1638012.

Sandell, R. (ed) (2003) Museums, Society, Inequality, London: Routledge.

Sayre, N.F. (2012) 'The Politics of the Anthropocene', Annual Review of Anthropology, 41 57-70.

Schorch, P. (2013) 'Contact Zones, Third Spaces, and the Act of Interpretation', Museum and Society, 11 (1) 68-81.

Smith, B.D. and Zeder, M.A. (2013) 'The Onset of the Anthropocene', Anthropocene, 4 8-13.

Steffen, W., Grinevald, J., Crutzen, P. and McNeill, J. (2011) 'The Anthropocene: Conceptual and Historical Perspectives', Philosophical Transactions of the Royal Society 369 842-67.

Swanson, H., Bubandt, N. and Tsing, A. (2015) 'Less Than One But More Than Many: Anthropocene as Science Fiction and Scholarship-in-the-Making', Environment and Society: Advances in Research, 6 149-66. 
TallBear, K. and Willey, A. (2019) 'Introduction: Critical Relationality: Queer, Indigenous, and Multispecies Belonging Beyond Settler Sex \& Nature', Imaginations, 10 (1)

5-15. DOI: $\underline{\mathrm{dx} . \mathrm{doi} . \mathrm{org} / 10.17742 / \text { IMAGE.CR.10.1.1. }}$.

Todd, Z. (2015) 'Indigenizing the Anthropocene', in Heather Davis and Etienne Turpin (eds) Art in the Anthropocene: Encounters Among Aesthetics, Politics, Environments and Epistemologies, 241-54, London: Open Humanities Press.

Trischler, H. (2016) 'The Anthropocene: A Challenge for the History of Science, Technology, and the Environment', NTM Zeitschrift für Geschicte der Wissenschaften, Technik und Medizin, 24 (3) 309-35.

Tsing, A., Swanson, H., Gan, E. and Bubandt, N. (eds) (2017) Arts of Living on a Damaged Planet: Ghosts and Monsters of the Anthropocene, Minnesota, University of Minnesota Press.

Tøndborg, B. (2013) 'The Dangerous Museum. Participatory Practices and Controversy in Museums Today', Nordisk Museologi, 2 3-16.

Verges, F. (2017) 'Racial Capitolocene', in Gaye Theresa Johnson and Alex Lubin (eds) Futures of Black Radicalism, 72-82, London; New York: Verso.

Williams. R. (1958) Culture and Society 1780-1950, London: Chatto and Windus.

(1961) The Long Revolution, London: Chatto and Windus.

(1976) Keywords: A Vocabulary of Culture and Society, London: Fontana.

Zalasiewicz, J., Williams, M., Haywood, A. and Ellis, M. (2011) 'The Anthropocene: A New Epoch of Geological Time?', Philosophical Transactions of the Royal Society 369, 835-41.

Zalasiewicz, J. et al. (2008) 'Are We Now Living in the Anthropocene?' GSA Today, 18, 4-8.

\section{Authors:}

Lotte Isager, Curator, anthropologist and geographer, PhD.

The Cultural History Museums in Holstebro

Museumsvej 2, DK-7500, Denmark.

Email: lotteisager@hotmail.com

Telephone: +4522627572

\section{Biographical note:}

Lotte Isager, anthropologist and geographer, Ph.d., is currently managing a research and communication project where university researchers and museum curators join forces in exploring how to use plants and ethnobotany to tell cultural history. Prior to this, she has worked for two decades at the University of Copenhagen on research about natural resource management, agricultural development and institutional capacity building in developing countries

Line Vestergaard Knudsen, Associate Professor

Department of Politics and Society, Aalborg University

Fibigerstræde 1,

DK 9220 Aalborg, Denmark

E-mail: vestergaard@dps.aau.dk,

Telephone: +45 24606909

Orcid: $0000-0003-1783-4397$ 


\section{Biographical note:}

Line Vestergaard Knudsen, Ph.d., researches and teaches museology and museum communication. By collaborating with several Danish cultural historical museums she studies and develops museum-society relationships. Has recently published studies of museum collaborations with public and private partners, and co-creative collaborations and participatory processes including users, digital developers and other stakeholders in museum projects. Currently, she is a member of a researcher/curator group that explores how to use plants and ethnobotany to tell cultural history.

Ida Theilade, Professor

Department of Food and Resource Economics (IFRO), University of Copenhagen Rolighedsvej 25, DK-1958 Frederiksberg C, Denmark

Email: idat@ifro.ku.dk

Telephone: +453533 1742

ORCID: $\underline{0000-0003-3502-1277}$

\section{Biographical note:}

Ida Theilade, Ph.d., teaches tropical botany and ethnobotany. Since the 1980s, she has conducted research on tropical forestry and botany, including management and conservation of forests and livelihoods in Southeast Asia and Africa. Her work as a conservation activist and her collaboration with groups of local non-state forest managers in Cambodia has won international acclaim. In Denmark, she is a keen participant in a collaborative project with five museums that explores how to use plants and ethnobotany to tell cultural history. 